\title{
Immunology for Renal Transplantation: A Review
}

\section{Badri M Shrestha*}

Division of Renal Transplantation, Sheffield Kidney Institute, Northern General Hospital, UK

*Corresponding author: Badri M Shrestha, Consultant Transplant Surgeon, Division of Renal Transplantation, Sheffield Kidney Institute, Herries Road, Sheffield, S5 7AU, UK, Tel: +44 114 2434343; Fax: +44 114 2714604; E-mail: shresthabm@doctors.net.uk

Rec date: Mar 23, 2014, Acc date: Apr 25, 2014, Pub date: Apr 27, 2014

Copyright: (c) 2014 Shrestha BM. This is an open-access article distributed under the terms of the Creative Commons Attribution License, which permits unrestricted use, distribution, and reproduction in any medium, provided the original author and source are credited.

\begin{abstract}
The current success of renal transplantation (RT) is the result of advancement in the understanding of the transplant immunology from gross allograft rejection to cellular and antibody response to the current molecular level. Laboratory assay technologies have been developed to characterise patient sensitisation and to detect pre-existing donor-specific antibodies (DSA) in pre-transplant crossmatch, which has helped prevent premature transplant losses from early and late antibody-mediated rejection. After a RT, pre-existing or de novo DSA are routinely monitored for modulation of immunosuppressive regimens. Therefore, it is mandatory for the personnel involved in the management of RT recipients to have clear understanding of the components of transplantation immunology and be familiar with the modern immunological techniques used in RT.
\end{abstract}

Keywords: Allorecognition; Human leucocyte antigen; Panel reactivity; Crossmatch; Donor-specific antibody; Rejection

\section{Introduction}

Since the first successful renal transplantation (RT) performed between the identical twins in the Peter Brent Brigham Hospital, Boston on 23rd December 1954 by Murray et al., RT has become a routine for the patients with end-stage renal disease. When a kidney is transplanted from a non-identical individual, the allograft; the recipient mounts an immune response termed as an alloimmune response [1]. The alloimmune response is initiated by the $\mathrm{T}$ cell recognition of the alloantigen and process is commonly known as the allorecognition. Allorecognition is the first step of the complex events that leads to $\mathrm{T}$ lymphocyte activation, antibody production, complement activation, allograft rejection and transplant failure [2] This review highlights the fundamental principles of transplant immunology and modern immunological assay techniques, which have important application in RT practice.

\section{HLA Molecules}

In humans, the major histocompatibility complex (MHC) genes code the strongest transplant antigens, which are called human leucocyte antigens (HLA). The HLA loci are located on the short arm of chromosome 6 [3]. The HLA haplotypes are inherited by the offspring from each parent in Mendelian co-dominant fashion. The Class I HLA are subdivided into HLA-A, $-\mathrm{B}$ and $-\mathrm{C}$ and is composed of a polymorphic heavy chain ( $\alpha$ chain, $44 \mathrm{kDa}$ ) and a nonpolymorphic light chain ( $\beta 2$-microglobulin, $12 \mathrm{kDa}$ ). Class I HLA molecules are expressed on all nucleated cells in the body and are involved in presenting endogenous small antigens (typically 9 to 11 amino acids), such as viruses and self-protein fragments in the context of self MHC to CD8+ T-lymphocytes. Class II HLA molecules (HLADP, $-D Q$, and $-D R)$ are composed of polymorphic $\alpha$ chain $(35 \mathrm{kDa})$ and a $\beta$ chain $(31 \mathrm{kDa})$ and are expressed on antigen presenting cells (APC) such as dendritic cells, macrophages, B cell, endothelial cells and some epithelial cells, which allow presentation of a diverse number of foreign peptides derived from the graft $[4,5]$. Proinflammatory cytokines released in response to any form of injury, upregulate the expression of HLA class II molecules on the epithelial and vascular endothelial cells, thereby enhancing allorecognition. Class II molecules present relatively larger antigens (12 to 28 amino acids) derived from extracellular proteins to CD4+ T-lymphocytes [6].

\section{HLA Matching}

The degree of HLA mismatch between the donor and recipient influences the risk of acute and chronic rejection, sensitisation and allograft survival. Traditionally, HLA-A, -B, and -DR (3 pairs and 6 antigens) are used for tissue typing and matching before RT. The sequencing of class I and II HLA loci used for histocompatibility testing include restriction fragment length polymorphism (RFLP), oligonucleotide hybridization and polymorphism-specific amplification using polymerase chain reaction and sequence-specific primers (PCR-SSP) [7-10]. Currently, the risk of rejection and sensitisation related to HLA-Cw, -DP, and -DQ mismatch is being increasingly recognised and therefore included in the tissue typing armamentarium in several transplant centres [11-13]. The major impact of HLA mismatch is seen from the match of DR antigen, and the order of importance for HLA match in RT is DR $>B>A$. For RT, the best long-term graft survival is seen following HLA-identical livingrelated RT [14,15].

\section{Non-HLA Antigens}

Despite a complete HLA match between the donor and recipient such as in HLA-identical siblings RT, acute and chronic rejection can occur, which is due to the presence of immune response to non-HLA antigens. There are reports of several non-HLA antigens and their antibodies derived from either alloimmunity or autoimmunity [16,17].

\section{ABO blood group antigens}

$\mathrm{ABO}$ blood group antigens play an important role in $\mathrm{RT}$, which are expressed on the red cells, most epithelial and endothelial cells and 
blood cells such as T cells, B cells and platelets where ABO antigens have adsorbed from plasma [18]. ABO incompatible RT leads to hyperacute rejection due to presence of preformed haemagglutinin $\mathrm{A}$ and/or B antibody. Akin to blood transfusion, compatibility of blood groups is essential in RT. The Rhesus factor and other red cell antigens are not relevant to organ transplants, as they are not expressed in vascular endothelium. The first attempt at $\mathrm{ABO}$ RT was reported in 1955 by Chung et al., where eight of ten ABOi kidney allografts did not work successfully within the first few postoperative days [19]. In 1987, Alexandre et al. introduced an effective desensitization protocol to achieve success in ABOi living donor RT. This protocol included pretransplant repeated plasmapheresis as a strategy not only to reduce the titres of anti-A or -B antibodies, but also to decrease the antilymphocyte globulin-based induction [20]. Transplanting kidneys from A2 or A2B into blood group B or O patients were carried out in the USA in 1986 resulting in $72 \% 10$ year graft survival of $72 \%$ for B recipients of an A2 or A2B kidneys which was equivalent to $69 \%$ graft survival to that $\mathrm{B}$ recipients of $\mathrm{B}$ kidneys [21].

\section{Minor histocompatibility antigens}

Besides the major HLA, there are small endogenous peptides, known as the minor histocompatibility antigen (MiHA), which occupy the antigen-binding sites of MHC molecules and are recognised by $\mathrm{Cd} 8+\mathrm{T}$-cells in the context of self -MHC leading to graft rejection. The H-Y MiHA is encoded by the Y chromosomes in males and can induce alloimmune response when a male organ is transplanted into a female recipient. MHC class 1 related chain A and B (MICA and $\mathrm{MICB}$ ) are expressed in endothelial cells. Antibody-mediated rejections occurring in the absence of DSA directed against HLA on many occasions are due to antibodies directed against MICA and /or MICB leading to transplant loss [22-24].

Other antibodies such as anti-angiotensin-2 receptor, antiglutathione S-transferase T1 and anti-endothelial antibodies are identified to be involved in causing AMR [25,26]. Anti-endothelial antibody can be detected by using donor monocyte for cross-match [27]. Some minor transplant antigens may come from mitochondrial proteins and enzymes [28]. In the future, several allo- and autoreactive antibodies are likely to be identified with the advancement of transplant immunology.

\section{Allorecognition and T Cell Activation}

In the donor kidney, particularly from a deceased donor, rapid swing in blood pressure and ischaemia leads to massive cytokine storm that activates the resident dendritic cells, vascular endothelium and tubular epithelial cells. Furthermore, ischaemia-reperfusion injury leads to cellular death and release of immunologically active molecules called damage-activates molecular patterns (DAMPs) such as heatshock proteins, adenosine triphosphate (ATP), uric acid, ribonucleic acid (RNA), deoxyribonucleic acid (DNA), as well as proteins derived from extracellular matrix including hyaluronan fragments and heparin sulphate proteoglycans [29,30]. Epithelial, mesenchymal and endothelial cells within the donor kidney express receptors for which include toll-like receptors (TLRs) and nucleotide-binding oligomerization domain-like receptors (NLRs), Interaction of the products of cellular injury with TLR and NLR sets of production of cytokines and chemokines, which are strong attractants for recipient innate immune cells [31-34].
Rejection of transplanted kidney involves both adaptive ( $\mathrm{T}$ and $\mathrm{B}$ cells) and innate (dendritic cells, macrophages, neutrophils, mast cells and natural killer cells) immune system, The innate immune system is activated by DAMPs, cytokines and chemokines released due to ischaemia-perfusion injury and microbial products, which once activated, triggers the adaptive immune system leading to cellular rejection. On the other hand, the activation stimulus to adaptive immune system is the alloantigens [35]. Allorecognition can occur by direct or indirect pathways. In the direct pathway, recipient's T cells recognise intact allogenic HLAs expressed in the donor cells. In the indirect pathway, $\mathrm{T}$ cells recognise peptides derived from the donor HLAs presented by the recipient APCs. In the immediate posttransplant period, the recipient $\mathrm{T}$-cells will recognise donor graft alloantigens if adequate immunosuppression is not achieved, leading to strong alloresponse and acute cellular rejection. The indirect pathway of allorecognition is predominant in the late onset of rejection, especially in chronic rejection, although this pathway may also participate in acute rejection. Therefore maintenance of immunosuppression is paramount for lifetime to prevent late acute and chronic rejection $[36,37]$.

The activation of the immune response begins in the recipient immediately after establishment of the vascular connection between the donor and recipient. First, the recipient is exposed to a torrent of chemicals, cytokines and chemokines derived from the ischaemic damaged kidney, which attracts the innate immune cells to infiltrate the organ adding to the ischaemia-reperfusion induced injury. Simultaneously, the activated dendritic migrate out of the graft to the T-cell rich regions of the recipient lymph nodes where they encounter nave recipient $\mathrm{T}$ cells, which is the key initiating event of $\mathrm{T}$ cell activation and cellular rejection [38]. The donor dendritic cells and recipient $\mathrm{T}$ cells engage each other using cell surface receptors, the HLA molecules on the dendritic cell and the T cell receptor (TCR), the junction is called an "immunological synapse". The TCR is comprised of an alpha chain and a beta chains and several associated molecules called the CD3 chains [39,40].

Included in the synapse are the juxtaposed $\mathrm{T}$ cell (TCR/CD3 complex) and the dendritic cell (HLA/peptide complex), which initiates the antigen-specific intracellular signal (signal 1). Simultaneously, additional molecules coalesce in the synapse to generate second signal called co-stimulation signal (signal 2), which is essential for complete $\mathrm{T}$ cell activation. Lack of signal 2 leads to either anergy or apoptosis $[36,39]$. The receptor-ligand interaction between $\mathrm{T}$-cells and the antigen presenting cells (APCs) which are involved in generation of co-stimulatory signals are CD28-B7 and CD154-CD40. CD28 and CD154 are expressed on T cells and their ligands B7 and CD40 are expressed on APCs. CD28 consists of two ligands, B7-1 (CD80) and B7-2 (CD86). T cells also express cytotoxic T-lymphocyte associated antigen-4 (CTLA-4), which is homologous to CD28, but has a higher affinity than CD28 to bind B7. Binding of CTLA-4 to B7 (both CD80 CD86) leads to generation of inhibitory signal to terminate $\mathrm{T}$ cell response [41,42].

Within seconds of assembly of immunological synapses, the combination of signal 1 and 2 activates three downstream signal transduction pathways within the cytoplasm of the T cell: the calciumcalcineurin pathway, the RAS-mitogen activated protein kinase (MAPK) pathway, and the IKK-nuclear factor қB (NF- қB) pathway [43-45]. The signals generated from through these three pathways reach the nucleus and activates gene transcription factors including the nuclear factor of activated T cells (NFAT), activated protein-1, and 
NF- $қ$, respectively. As a result of gene transcription, several new molecules and cytokines including CD25, CD154, interleukin-2 (IL-2) and interferon- $\gamma$ (IFN- $\gamma$ ) are secreted and their receptors expressed [46]. IL-2 binds to its own receptor on the surface of T cell in autocrine fashion (signal 3), which, activates the mammalian target of rapamycin (mTOR) pathway, phosphoinositide-3-kinase (PI3K) pathway and Janus kinase/signal transducers and activators of transcription protein pathway (JAK/STAT), which allow the activated $\mathrm{T}$ cells to progress through the cell division cycle and clonal expansion of donor HLA/ peptide -specific effector (CD8+ cytotoxic $\mathrm{T}$ cells) $\mathrm{T}$ cells $[47,48]$. These cells produce CD8+ T-cell mediated cytotoxicity, help macrophage-induced delayed type hypersensitivity response (CD4+Th1) and help B cells for antibody production (CD4+Th2) [49,50]. A subset of activated T cells (CD4 or CD8) survive in an inactive state for a long period, called the memory $\mathrm{T}$ cells, but will quickly expand and mount an aggressive immune when re-exposed to the same foreign protein [51].

Tacrolimus and cyclosporine inhibit calcineurin leading to blockade of IL-2 gene transcription and development of cytotoxic $\mathrm{T}$ lymphocytes [52]. Anti-IL-2 receptor blockade with monoclonal antibodies such as basiliximab and daclizumab and mTOR inhibitor such as sirolimus and everolimus have been successful in inhibiting $\mathrm{T}$ cell activation and reduce the incidence of acute rejection $[53,54]$.

\section{T Cell-Mediated Cytotoxicity}

Physiological cytotoxicity is mediated by $\mathrm{CD} 8+\mathrm{T}$ cells because they bind to the class I MHC of all nucleated cells. Killing occurs either by a calcium-dependent secretory mechanism or a calcium-independent mechanism that requires direct contact [55]. The influx of calcium during the activation causes exocytosis of cytolytic granules containing a lytic protein called perforin and serine proteases granzymes. Perforin forms a defect in the target cell membrane allowing granzyme activity to lyse the cell. In the absence of calcium, cytotoxic T cells upregulate fas ligand upon activation, which can then bind to fas on the target cells, leading to apoptosis, which is a programmed cell death that involves fragmentation of nuclear contents [56,57].

\section{Role of B Lymphocytes}

B cells recognise antigens in its native form without the requirement of processing and presentation on MHC molecules [58]. Cross-linking of antigen to the antigen-specific surface antibodies stimulates B cell activation, proliferation, and differentiation in to a plasma cell. Some activated B cells become memory B cells. B cells also internalise antigens, process them and present to the $\mathrm{T}$ cells through the indirect pathway of allorecognition. They receive signals from $\mathrm{T}$ cells via CD40 by binding to the $\mathrm{T}$ cell $\mathrm{CD} 40 \mathrm{~L}$, which upregulate expression of $\mathrm{B} 7$ molecules on $\mathrm{B}$ cells and facilitate antigen presentation and $\mathrm{T}$ cell costimulation [59]. The anti-HLA antibodies produced by plasma cells bind alloantigen and cause graft injury either by activating the complement cascade known as complementdependent cytotoxicity (CDC) or via Fc receptor in the natural killer (NK) cells, neutrophils and antibody-dependent cellular cytotoxicity [60].

\section{Donor-specific Antibodies}

Plasma cells can produce antibodies against both HLA and nonHLA antigens. Non-HLA antibodies directed against donor endothelial antigens such as MHC class I polypeptide-related sequence
A or B (MICA and MICB), smooth muscle antigen (vimentin), collagen- $\mathrm{V}$ and cell surface receptor such a type I angiotensin II receptor are reliably detected by currently available techniques [61]. Donor-specific antibodies (DSA) are measures routinely posttransplantation to detect the reactivity of the recipient $\mathrm{B}$ cells against the donor antigens. If the titre of the specific DSA rises suggesting inadequate immunosuppression, several therapeutic options, including plasmapheresis, thymoglobulin, intravenous immunoglobulin (IVIG), and anti-CD20 antibody (rituximab) can be attempted [62-64]. Emerging therapies include proteasome inhibitors such as Bortezomib [65]. Several studies have suggested that DSA to HLA antigens and endothelial antigens may be a driver not only of acute antibody-mediate rejection (AMR) but also chronic rejection [66].

\section{Sensitisation and Panel Reactivity}

Sensitisation is defined by the presence of antibodies in the recipient blood against a panel of selected HLA antigens representing donor population, which is reported as percentage panel reactivity (PRA). PRA estimates the likelihood of positive crossmatch to potential donors. The higher is the PRA level; the lower becomes the chance of receiving compatible kidney and longer the waiting time on the waitlist [67]. Sensitisation is caused by exposure to HLA antigens through failed previous transplants, pregnancy and blood transfusion $[68,69]$. The percent PRA in an individual may vary from time to time due either to a change in the antibody titre, or a change in the usage of HLA antigens in the assay. The technology of PRA assay has advanced significantly from the initial CDC assay to solid phase based enzymelinked immunosorbent assay (ELISA), to a current multiplexed particle-based flow cytometry (Luminex). Single antigen beads are increasingly used to characterise the preformed HLA antibodies before $\mathrm{RT}$ and to detect development DSA after RT [70].

\section{Crossmatch}

When a potential donor is identified, a crossmatch with fresh serum from recipient and lymphocytes from donor has to be performed to exclude preformed DSA, which can lead hyperacute AMR. The final crossmatch must be negative to proceed with RT. CDC crossmatch and flow cytometry (FCXM) are two commonly used methods, although the choice is dependent on individual centre experience and their availability $[71,72]$.

T cells express class I antigens only, while B cells express both HLA class I and class II antigens. Furthermore, there is significantly increased expression of HLA class I antigens in B cells compared to T cells. A positive $T$ cell crossmatch is considered as true and significant sensitisation with DSA against HLA class I antigens. A negative T cell crossmatch and a positive $B$ cell crossmatch may represents presence of either HLA class II antibodies or low titre of HLA class I antibodies. A positive $T$ cell crossmatch associated with a negative $B$ cell crossmatch is likely to be due to the presence of non-HLA antibodies [73-75].

The antigens corresponding to preformed HLA antibodies are considered unacceptable for that patient. So a patient will not be offered a kidney from a deceased donor, who expresses an unacceptable HLA antigen (positive virtual crossmatch). Only those patients whose HLA antibodies are not donor directed will appear on the matching run (negative virtual crossmatch). Virtual crossmatch is increasing used in clinical practice as this has improved the efficiency 
of organ allocation by decreasing the risk of positive crossmatch and cold ischaemia time $[76,77]$.

\section{Complement-dependent Cytotoxicity Crossmatch}

The donor $\mathrm{T}$ and $\mathrm{B}$ lymphocytes are isolated from lymph nodes and blood, and placed in wells, where the recipient serum and rabbit complement are added. The cytotoxicity is determined by counting the lysis of the lymphocytes compared to the control. Antihuman globulin is added to increase the sensitivity (AHG-CDC), as antihuman globulin can induce cross-linking of antibodies and increases the visual cytotoxicity [78]. If the CDC crossmatch becomes positive, this is repeated with addition of dithiothreitol (DTT), which reduces the disulphide bonds of the immunoglobulin (Ig)M if it present and makes the crossmatch negative in the presence of IgM antibodies [79]. A positive CDC crossmatch before and after treatment with DTT indicate the presence of DSA of IgG nature. IgM antibodies are generally not considered to cause real sensitisation. In the presence of a positive CDC cross match secondary to a cytotoxic IgG anti-HLA antibody, RT should not proceed, unless a desensitisation protocol is adopted to remove the preformed DSA and a negative crossmatch is achieved [80].

\section{Flow Cytometric Crossmatch}

In RT, Flow Cytometric Cross Match (FCXM) represents the most sensitive method of demonstrating the binding HLA antibodies and has revolutionised the HLA antibody assessment and facilitated improved allograft survival among highly sensitised recipients. The FCXM is performed by incubating donor lymphocytes with recipient serum after addition of fluorochrome-labeled antihuman IgG. The amount of measured fluorescence, that is the channel shift in the fluorescence intensity, is proportional to the amount of antibody bound to the target cell $[81,82]$. In order to help differentiate the class of antibody that may be binding to the lymphocytes, labelled monoclonal antibodies are used to identify T-cells (CD3) or B-cells (CD19). FCXM is much more sensitive than CDC or AHG-CDC in detecting low level antibodies. Non-cytotoxic antibodies can also be detected with FCXM since it is not dependent on complement activation of the antibody. Single antigen bead (Luminex) can be used to further to determine if the DSA is responsible for the channel shift in the FCXM $[83,84]$.

The CDC and FCXM differ in their degree of sensitivity. FCXM significantly reduces the incidence of post-RT AMR, but it may also be too sensitive to detect clinically irrelevant antibodies there by denying opportunity to some potential transplants [85]. Crossmatch tests can also be performed with the recipient's previous sera. A negative crossmatch for current sera and positive for historical sera suggests previous antibodies which may have waned in titre [86]. The specific memory B cells could rapidly expand and produce antibodies when reexposed to specific alloantigen. There is an increased risk of AMR, but this situation is not a contra-indication for a RT. Close monitoring of DSA and immunosuppression is essential $[87,88]$.

\section{Tolerance}

In order to meet the growing need of organs for transplantation, induction of tolerance to an organ allograft is under investigation. Tolerance is characterised by the specific lack of unrestrained adverse immune reactivity, the maintenance of which does not require chronic immunosuppression. Transplantation of donor bone marrow to condition recipients leads to a state of mixed chimerism, where the recipient and donor haemopoietic cells co-exist. This induces tolerance allowing successful withdrawal of chronic immunosuppression in both animal and human models posttransplantation $[89,90]$. Blockade of CD28 using CTLA4Ig has been successful in inducing tolerance of human pancreatic cells in diabetic mice [91]. Several types of T cells with immunosuppressive properties have been identified, but FOXP3+ regulatory T (TREG) cells have emerged as a dominant cell type; they are critically involved in the induction and maintenance of immune tolerance. Manipulation of this cell type for the induction of transplant tolerance including renal transplant tolerance has attracted considerable attention [92]. Belatacept, a recombinant fusion protein composed of the $\mathrm{Fc}$ fragment of a human IgG1 immunoglobulin linked to the extracellular domain of CTLA-4, which is a molecule crucial for T-cell costimulation, is effective in induction of tolerance through co-stimulation blockade and inhibition of generation of allogenic-specific TREG cells in human $[93,94]$.

\section{Xenotransplantation}

Transplanting organs from animal sources, xenotransplantation (XT), remains in the experimental stage. Hyperacute rejection due to the presence of galactose- $\alpha 1,3$-galactose (Gal) antibodies in man against the Gal-al,3-Gal antigen present in the pig organs $[95,96]$, is the major barrier to XT. This is being overcome by breeding transgenic pigs that express human decay accelerating factor on their vascular endothelium [97]. Alternatively the production of cloned $\alpha-1,3-$ Gal knockout pigs, through elimination of the gene that encodes for the a1,3-galactosyl transferase enzyme necessary for the generation of $\alpha$-Gal epitope, may prevent complement activation and hyperacute rejection [98]. Xenozoonoses derived from the transfer of porcine endogenous retrovirus is the major risk of xenotransplantation [99]. Other strategies used are the establishment of xenogenic tolerance through mixed chimerism [100] and thymic transplantation [101].

\section{Conclusion}

Understanding of the immunology related to RT, advances in the techniques of detection and characterisation of antibodies before and after RT and the crossmatch techniques have significantly improved the outcomes of RT over last two decades. A late allograft loss from chronic antibody-mediated rejection still remains a major problem, which needs further research to advance our understandings of the immunological process involved that would help to reduce the transplant losses.

\section{References}

1. Merrill JP, Murray JE, Harrison JH, Guild WR (1984) Landmark article Jan 28, 1956: Successful homotransplantation of the human kidney between identical twins. By John P. Merrill, Joseph E. Murray, J. Hartwell Harrison, and Warren R. Guild. JAMA 251: 2566-2571.

2. Halloran PF (2004) Immunosuppressive drugs for kidney transplantation. N Engl J Med 351: 2715-2729.

3. Campbell RD, Trowsdale J (1993) Map of the human MHC. Immunol Today 14: 349-352.

4. Bjorkman PJ, Saper MA, Samraoui B, Bennett WS, Strominger JL, et al. (1987) The foreign antigen binding site and $\mathrm{T}$ cell recognition regions of class I histocompatibility antigens. Nature 329: 512-518. 
5. Bjorkman PJ, Saper MA, Samraoui B, Bennett WS, Strominger JL, et al. (1987) Structure of the human class I histocompatibility antigen, HLAA2. Nature 329: 506-512.

6. Halloran PF, Madrenas J (1990) Regulation of MHC transcription. Transplantation 50: 725-738.

7. Bidwell J (1988) DNA-RFLP analysis and genotyping of HLA-DR and DQ antigens. Immunol Today 9: 18-23.

8. Nevinny-Stickel C, Bettinotti MD, Andreas A, Hinzpeter M, Mühlegger K, et al. (1991) Nonradioactive HLA class II typing using polymerase chain reaction and digoxigenin-11-2'-3'-dideoxy-uridinetriphosphatelabeled oligonucleotide probes. Hum Immunol 31: 7-13.

9. Nevinny-Stickel C, Hinzpeter M, Andreas A, Albert ED (1991) Nonradioactive oligotyping for HLA-DR1-DRw10 using polymerase chain reaction, digoxigenin-labelled oligonucleotides and chemiluminescence detection. Eur J Immunogenet 18: 323-332.

10. Olerup O, Zetterquist H (1992) HLA-DR typing by PCR amplification with sequence-specific primers (PCR-SSP) in 2 hours: an alternative to serological DR typing in clinical practice including donor-recipient matching in cadaveric transplantation. Tissue Antigens 39: 225-235.

11. Billen EV, Christiaans MH, Doxiadis II, Voorter CE, van den BergLoonen EM (2010) HLA-DP antibodies before and after renal transplantation. Tissue Antigens 75: 278-285.

12. Freedman BI, Thacker LR, Heise ER, Adams PL (1997) HLA-DQ matching in cadaveric renal transplantation. Clin Transplant 11: 480-484.

13. Skerrett D, Rosina O, Bodian C, Isola L, Gudzowaty O, et al. (2001) Human leukocyte antigens (HLA)-Cw as prognostic indicators in autologous transplantation for lymphoma. Cancer Invest 19: 487-494.

14. Morris PJ, Johnson RJ, Fuggle SV, Belger MA, Briggs JD (1999) Analysis of factors that affect outcome of primary cadaveric renal transplantation in the UK. HLA Task Force of the Kidney Advisory Group of the United Kingdom Transplant Support Service Authority (UKTSSA). Lancet 354: 1147-1152.

15. Solheim BG, Flatmark A, Enger E, Jervell J, Thorsby E (1977) Influence of HLA-A, -B, -C, and -D matching on the outcome of clinical kidney transplantation. Transplant Proc 9: 475-478.

16. Gerrits JH, van de Wetering J, Drabbels JJ, IJzermans JN, Claas FH, et al. (2009) Non-HLA T-cell reactivity during the first year after HLAidentical living-related kidney transplantation. Clin Transplant 23: 740-747.

17. Rodríguez PC, Arroyave IH, Mejía G, García LF (2000) Detection of alloantibodies against non-HLA antigens in kidney transplantation by flow cytometry. Clin Transplant 14: 472-478.

18. Yoshida A (1981) Genetic mechanism of blood group (ABO)-expression. Acta Biol Med Ger 40: 927-941.

19. Chung BH, Lee JY, Kang SH, Sun IO, Choi SR, et al. (2011) Comparison of patient outcome according to renal replacement modality after renal allograft failure. Ren Fail 33: 261-268.

20. Thielke J, Kaplan B, Benedetti E (2007) The role of ABO-incompatible living donors in kidney transplantation: state of the art. Semin Nephrol 27: 408-413.

21. Bryan CF, Nelson PW, Shield CF 3rd, Ross G, Warady B, et al. (2004) Transplantation of A2 and A2B kidneys from deceased donors into B waiting list candidates increases their transplantation rate. Clin Transpl .

22. Sapák M, Chreňová S, Tirpáková J, Žilinská Z, Duurmanová V, et al. (2014) Donor non-specific MICA antibodies in renal transplant recipients. Immunobiology 219: 109-112.

23. Suárez-Alvarez B, López-Vázquez A, Díaz-Peña R, Díaz-Molina B, Blanco-García RM, et al. (2006) Post-transplant soluble MICA and MICA antibodies predict subsequent heart graft outcome. Transpl Immunol 17: 43-46.

24. Zwirner NW, Marcos CY, Mirbaha F, Zou Y, Stastny P (2000) Identification of MICA as a new polymorphic alloantigen recognized by antibodies in sera of organ transplant recipients. Hum Immunol 61: 917-924.
25. Aguilera I, Wichmann I, Gentil MA, Gonzalez-Escribano F, NuñezRoldan A (2005) Antibodies against the donor antigen glutathione Stransferase T1 after renal transplantation. Transplant Proc 37: 1457-1458.

26. Reinsmoen NL (2013) Role of angiotensin II type 1 receptor-activating antibodies in solid organ transplantation. Hum Immunol 74: 1474-1477.

27. Cerilli J, Holliday JE, Fesperman DP, Folger MR (1977) Antivascular endothelial cell antibody--its role in transplantation. Surgery 81: 132-138.

28. Davies JD, Silvers WK, Wilson DB (1992) A transplantation antigen, possibly of mitochondrial origin, that elicits rejection of parental strain skin grafts by F1 rats. Transplantation 54: 730-731.

29. Bianchi ME (2007) DAMPs, PAMPs and alarmins: all we need to know about danger. J Leukoc Biol 81: 1-5.

30. Herrero I, Torras J, Riera M, Condom E, Coll O, et al. (1999) Prevention of cold ischaemia-reperfusion injury by an endothelin receptor antagonist in experimental renal transplantation. Nephrol Dial Transplant 14: 872-880.

31. Kawai T, Akira S (2009) The roles of TLRs, RLRs and NLRs in pathogen recognition. Int Immunol 21: 317-337.

32. Bergler T, Hoffmann U, Bergler E, Jung B, Banas MC, et al. (2012) Tolllike receptor 4 in experimental kidney transplantation: early mediator of endogenous danger signals. Nephron Exp Nephrol 121: e59-70.

33. Krüger B, Krick S, Dhillon N, Lerner SM, Ames S, et al. (2009) Donor Toll-like receptor 4 contributes to ischemia and reperfusion injury following human kidney transplantation. Proc Natl Acad Sci U S A 106: 3390-3395.

34. Nogueira E, Ozaki KS, Macusso GD, Quarim RF, Câmara NO, et al. (2007) Incidence of donor and recipient toll-like receptor-4 polymorphisms in kidney transplantation. Transplant Proc 39: 412-414.

35. He H, Stone JR, Perkins DL (2003) Analysis of differential immune responses induced by innate and adaptive immunity following transplantation. Immunology 109: 185-196.

36. Game DS, Lechler RI (2002) Pathways of allorecognition: implications for transplantation tolerance. Transpl Immunol 10: 101-108.

37. Vartdal F, Thorsby E (1999) Transplantation immunology--the role of human leucocyte antigen in allorecognition. Curr Top Pathol 92: 1-18.

38. Ponticelli C (2013) Ischaemia-reperfusion injury: a major protagonist in kidney transplantation. Nephrol Dial Transplant.

39. Halloran PF (1999) T-cell activation pathways: a transplantation perspective. Transplant Proc 31: 769-771.

40. Sim GK, Yagüe J, Nelson J, Marrack P, Palmer E, et al. (1984) Primary structure of human T-cell receptor alpha-chain. Nature 312: 771-775.

41. Snanoudj R, Zuber J, Legendre C (2010) Co-stimulation blockade as a new strategy in kidney transplantation: benefits and limits. Drugs 70: 2121-2131.

42. Poirier N, Blancho G, Vanhove B (2010) Alternatives to calcineurin inhibition in renal transplantation: belatacept, the first co-stimulation blocker. Immunotherapy 2: 625-636.

43. Strehlau J, Pavlakis M, Lipman M, Maslinski W, Shapiro M, et al. (1996) The intragraft gene activation of markers reflecting T-cell-activation and -cytotoxicity analyzed by quantitative RT-PCR in renal transplantation. Clin Nephrol 46: 30-33.

44. Huang GN, Huso DL, Bouyain S, Tu J, McCorkell KA, et al. (2008) NFAT binding and regulation of $\mathrm{T}$ cell activation by the cytoplasmic scaffolding Homer proteins. Science 319: 476-481.

45. Zhao Z, Wang L, Yang C, Zhao T, Li L, et al. (2013) Soluble FGL2 induced by tumor necrosis factor-ÎI \pm and interferon- $\hat{I}^{3}$ in $\mathrm{CD} 4+\mathrm{T}$ cells through MAPK pathway in human renal allograft acute rejection. J Surg Res 184: 1114-1122.

46. Young-Fadok TM, Simpson MA, Madras PN, Dempsey RA, O'Connor K, et al. (1991) Predictive value of pretransplant IL-2 levels in kidney transplantation. Transplant Proc 23: 1295-1296.

47. Taniguchi T, Minami Y (1993) The IL-2/IL-2 receptor system: a current overview. Cell 73: 5-8

48. Flanagan ME, Blumenkopf TA, Brissette WH, Brown MF, Casavant JM, et al. (2010) Discovery of CP-690,550: a potent and selective Janus kinase 
(JAK) inhibitor for the treatment of autoimmune diseases and organ transplant rejection. J Med Chem 53: 8468-8484.

49. Goldman M, Druet P (1995) The TH1/TH2 concept and its relevance to renal disorders and transplantation immunity. Nephrol Dial Transplant 10: $1282-1284$.

50. Nickerson P, Steurer W, Steiger J, Zheng X, Steele AW, et al. (1994) Cytokines and the Th1/Th2 paradigm in transplantation. Curr Opin Immunol 6: 757-764.

51. Bingaman AW, Farber DL (2004) Memory T cells in transplantation: generation, function, and potential role in rejection. Am J Transplant 4: 846-852.

52. Lo A (2004) Strategies to prevent chronic allograft nephropathy in kidney transplantation: focus on calcineurin inhibitors. Prog Transplant 14 157-164.

53. Olyaei AJ, Thi K, deMattos AM, Bennett WM (2001) Use of basiliximab and daclizumab in kidney transplantation. Prog Transplant 11: 33-37.

54. Rogers J, Ashcraft EE, Emovon OE, Baillie GM, Taber DJ, et al. (2004) Long-term outcome of sirolimus rescue in kidney-pancreas transplantation. Transplantation 78: 619-622.

55. Berke G (1995) The CTL's kiss of death. Cell 81: 9-12.

56. Pascoe MD, Marshall SE, Welsh KI, Fulton LM, Hughes DA (2000) Increased accuracy of renal allograft rejection diagnosis using combined perforin, granzyme $\mathrm{B}$, and Fas ligand fine-needle aspiration immunocytology. Transplantation 69: 2547-2553.

57. Sharma VK, Bologa RM, Li B, Xu GP, Lagman M, et al. (1996) Molecular executors of cell death--differential intrarenal expression of Fas ligand, Fas, granzyme B, and perforin during acute and/or chronic rejection of human renal allografts. Transplantation 62: 1860-1866.

58. Cambier JC, Pleiman CM, Clark MR (1994) Signal transduction by the B cell antigen receptor and its coreceptors. Annu Rev Immunol 12: 457-486.

59. Lederman S, Yellin MJ, Inghirami G, Lee JJ, Knowles DM, et al. (1992) Molecular interactions mediating T-B lymphocyte collaboration in human lymphoid follicles. Roles of T cell-B-cell-activating molecule (5c8 antigen) and CD40 in contact-dependent help. J Immunol 149: 3817-3826.

60. Muro M, Llorente S, Marin L, Moya-Quiles MR, Gonzalez-Soriano MJ, et al. (2005) Acute vascular rejection mediated by HLA antibodies in a cadaveric kidney recipient: discrepancies between FlowPRA, ELISA and CDC vs luminex screening. Nephrol Dial Transplant 20: 223-226.

61. Dragun D, Philippe A, Catar R (2012) Role of non-HLA antibodies in organ transplantation. Curr Opin Organ Transplant 17: 440-445.

62. Ginevri F, Nocera A, Comoli P, Innocente A, Cioni M, et al. (2012) Posttransplant de novo donor-specific hla antibodies identify pediatric kidney recipients at risk for late antibody-mediated rejection. Am J Transplant 12: 3355-3362.

63. Riethmuller S, Ferrari-Lacraz S, Muller MK, Raptis DA, Hadaya K, et al. (2010) Donor-specific antibody levels and three generations of crossmatches to predict antibody-mediated rejection in kidney transplantation. Transplantation 90: 160-167.

64. Fidler ME, Gloor JM, Lager DJ, Larson TS, Griffin MD, et al. (2004) Histologic findings of antibody-mediated rejection in ABO blood-groupincompatible living-donor kidney transplantation. Am J Transplant 4: 101-107.

65. Sureshkumar KK, Hussain SM, Marcus RJ, Ko TY, Khan AS, et al. (2012) Proteasome inhibition with bortezomib: an effective therapy for severe antibody mediated rejection after renal transplantation. Clin Nephrol 77: 246-253.

66. Rose ML (1998) Endothelial cells as antigen-presenting cells: role in human transplant rejection. Cell Mol Life Sci 54: 965-978.

67. Bostock IC, Alberú J, Arvizu A, Hernández-Mendez EA, De-Santiago A, et al. (2013) Probability of deceased donor kidney transplantation based on \% PRA. Transpl Immunol 28: 154-158.

68. Mizutani K (2007) HLA mismatches and PRA in kidney retransplants. Clin Transpl
69. Kallich JD, Wyant T, Krushat M (1990) The effect of DR antigens, race, sex, and peak PRA on estimated median waiting time for a first cadaver kidney transplant. Clin Transpl .

70. Rebibou JM, Chabod J, Bittencourt MC, Thevenin C, Chalopin JM, et al. (2000) Flow-PRA evaluation for antibody screening in patients awaiting kidney transplantation. Transpl Immunol 8: 125-128.

71. Cook DJ, Terasaki PI, Iwaki Y, Terashita G, Takeda A, et al. (1987) The flow cytometry crossmatch in kidney transplantation. Clin Transpl .

72. d-Orchimont RC, Dupont E, Vereerstraeten P, Kinnaert P, Richnard C (1978) Crossmatch test in kidney transplantation. Nephron 20: 178-179.

73. Evans PR, Trickett LP, Gosney AR, Hodges E, Shires S, et al. (1988) Detection of kidney reactive antibodies at crossmatch in renal transplant recipients. Transplantation 46: 844-852.

74. Ogura K, Terasaki PI, Johnson C, Mendez R, Rosenthal JT, et al. (1993) The significance of a positive flow cytometry crossmatch test in primary kidney transplantation. Transplantation 56: 294-298.

75. Patel R, Terasaki PI (1969) Significance of the positive crossmatch test in kidney transplantation. N Engl J Med 280: 735-739.

76. Ferrari P, Fidler S, Wright J, Woodroffe C, Slater P, et al. (2011) Virtual crossmatch approach to maximize matching in paired kidney donation. Am J Transplant 11:272-278.

77. Bingaman AW, Murphey CL, Palma-Vargas J, Wright F (2008) A virtual crossmatch protocol significantly increases access of highly sensitized patients to deceased donor kidney transplantation. Transplantation 86: 1864-1868.

78. Nanni-Costa A, Scolari MP, Iannelli S, Buscaroli A, De Sanctis LB, et al. (1997) Crossmatch testing in renal transplantation: comparative evaluation between an innovatory ELISA technique and two different standardised CDC methods. Transplant Proc 29: 1449-1450.

79. Raffoux C, Sabah C, Hors J, Busson M, Ozdemir E, et al. (1990) Improvement of crossmatch using dithiothreitol before kidney transplantation. Transplant Proc 22: 1889.

80. Akalin E, Ames S, Sehgal V, Fotino M, Daly L, et al. (2003) Intravenous immunoglobulin and thymoglobulin facilitate kidney transplantation in complement-dependent cytotoxicity B-cell and flow cytometry T- or Bcell crossmatch-positive patients. Transplantation 76: 1444-1447.

81. Michalska K, Korczak-Kowalska G, PodobiÅ,ska I, Durlik M, Wyzgå̊, J, et al. (2002) Flow cytometry crossmatch in living donor renal transplantation. Transplant Proc 34: 689-690.

82. Nehlsen-Cannarella SL (1992) Flow cytometry for crossmatch evaluation in renal transplantation. Nephron 62: 233-235.

83. Lentine KL, Graff RJ, Xiao H, Modanlou KA, Salvalaggio PR, et al. (2008) Flow cytometry crossmatch before kidney transplantation in contemporary practice: target cell utilization, results patterns, and associated long-term graft survival. Clin Transpl 253-266.

84. Vaidya S, Partlow D, Susskind B, Noor M, Barnes T, et al. (2006) Prediction of crossmatch outcome of highly sensitized patients by single and/or multiple antigen bead luminex assay. Transplantation 82: 1524-1528.

85. Wahlberg J, Bengtsson M, Bergström C, Gannedahl G, Festin R, et al. (1994) Impact of flow cytometry cross-matching results on the outcome of cadaveric kidney transplantation. Transplant Proc 26: 1752-1753.

86. Graff RJ, Buchanan PM, Dzebisashvili N, Schnitzler MA, Tuttle-Newhall J, et al. (2010) The clinical importance of flow cytometry crossmatch in the context of CDC crossmatch results. Transplant Proc 42: 3471-3474.

87. Wu P, Jin J, Everly MJ, Lin C, Terasaki PI, et al. (2013) Impact of alloantibody strength in crossmatch negative DSA positive kidney transplantation. Clin Biochem 46: 1389-1393.

88. Mohamed MA, Muth B, Vidyasagar V, Foley D, Fernandez L, et al. (2011) Post-transplant DSA monitoring may predict antibody-mediated rejection in sensitized kidney transplant recipients. Clin Transpl.

89. Pilat N, Wekerle $\mathrm{T}$ (2010) Transplantation tolerance through mixed chimerism. Nat Rev Nephrol 6: 594-605.

90. Billingham RE, Brent L, Medawar PB (1953) Actively acquired tolerance of foreign cells. Nature 172: 603-606. 
Citation: Shrestha BM (2014) Immunology for Renal Transplantation: A Review. J Transplant Technol Res 4: 130. doi: 10.4172/2161-0991.1000130

Page 7 of 7

91. Lenschow DJ, Zeng Y, Thistlethwaite JR, Montag A, Brady W, et al. (1992) Long-term survival of xenogeneic pancreatic islet grafts induced by CTLA4lg. Science 257: 789-792.

92. Li XC, Turka LA (2010) An update on regulatory T cells in transplant tolerance and rejection. Nat Rev Nephrol 6: 577-583.

93. Vincenti F, Larsen C, Durrbach A, Wekerle T, Nashan B, et al. (2005) Costimulation blockade with belatacept in renal transplantation. $\mathrm{N}$ Engl J Med 353: 770-781.

94. Levitsky J, Miller J, Huang X, Chandrasekaran D, Chen L, et al. (2013) Inhibitory effects of belatacept on allospecific regulatory $\mathrm{T}$-cell generation in humans. Transplantation 96: 689-696.

95. Good AH, Cooper DK, Malcolm AJ, Ippolito RM, Koren E, et al. (1992) Identification of carbohydrate structures that bind human antiporcine antibodies: implications for discordant xenografting in humans. Transplant Proc 24: 559-562.

96. Cooper DK, Good AH, Koren E, Oriol R, Malcolm AJ, et al. (1993) Identification of alpha-galactosyl and other carbohydrate epitopes that are bound by human anti-pig antibodies: relevance to discordant xenografting in man. Transpl Immunol 1: 198-205.

97. Cozzi E, White DJ (1995) The generation of transgenic pigs as potential organ donors for humans. Nat Med 1: 964-966.

98. Cooper DK, Koren E, Oriol R (1993) Genetically engineered pigs. Lancet 342: 682-683.

99. Stoye JP, Le Tissier P, Takeuchi Y, Patience C, Weiss RA (1998) Endogenous retroviruses: a potential problem for xenotransplantation? Ann N Y Acad Sci 862: 67-74.

100. Sachs DH, Sykes M, Robson SC, Cooper DK (2001) Xenotransplantation. Adv Immunol 79: 129-223.

101. Zhao Y, Fishman JA, Sergio JJ, Oliveros JL, Pearson DA, et al. (1997) Immune restoration by fetal pig thymus grafts in $\mathrm{T}$ cell-depleted, thymectomized mice. J Immunol 158: 1641-1649. 